\title{
Ready-to-wear sexual politics: The semiotics of visibility on Wits Pride T-shirts
}

\author{
Tommaso M. Milani and Koki Kapa \\ Linguistics, University of the Witwatersrand, Johannesburg, South Africa \\ E-mail: Tommaso.Milani@wits.ac.za; blackstar_koki@yahoo.com
}

\begin{abstract}
The aim of this article is to investigate T-shirts as semiotic tools of the politics of visibility, showing which role these sartorial artefacts may play in competing struggles for recognition in which gender and sexuality intersect with other axes of social categorisations. Drawing on a queer multimodal approach, the article offers an analysis of the four promotional T-shirts that were distributed each year between 2011 and 2014 by the Transformation and Employment Equity Office at the University of the Witwatersrand (Wits), Johannesburg, in the context of the annual Pride parade on campus. Our main argument is that changes over time in the design of Wits Pride T-shirts represent a shift both in what is claimed to be the main goal of campus sexual politics and in the proposed means to achieve such a goal. If one were to imagine that each T-shirt is a corporeal embodiment of Wits Pride, then this body has changed considerably in four years: from a gay man who is (supposedly) ashamed of voicing his sexual identity; into a camp though masculine figure that loudly urges to counter racial division within same-sex desire; into a more multifaceted individual who proudly carries their gender and sexual uniqueness; and finally, into an activist who, in tension with the complex intersections that underpin discrimination, is perhaps a little reluctant to foreground gender and sexuality at all.
\end{abstract}

Keywords: gender, multimodality, visual analysis, queer, sexuality

\section{Introduction}

At a recent lecture on the rights of lesbian, gay, bisexual, transgender, intersex, asexual, queer and other (LGBTIAQ+) sexual identities in Africa, Constitutional Court Justice Edwin Cameron declared that "[v]isibility is what starts the process to get equality. All strategies start with visibility" (Mabula 2015). Not all supporters of gender and sexual rights would, however, agree. Writing about the United States (US), Phelan (1997) cautions that

[v]isibility [...] is not one thing, nor is it necessarily and always good. Assertions that visibility is essential to gay and lesbian citizenship [...] introduce further questions: Who among these diverse groups is to be visible? Is all visibility good? Certainly, many gay [lesbian, bisexual, transgender and 
queer] activists are profoundly uneasy with the images they see on TV and in print media following any pride march, or any week on a talk show.

(Phelan 1997: 6)

Phelan (1997) therefore encourages us to undertake careful analyses of the different guises visibility may take in relation to sexual politics, and unpack the discursive strategies that, in the pursuit of equality, foreground certain nexus points of gender, sexuality and other social categories, while simultaneously backgrounding or erasing others.

It is in such a vein that this article aims to deconstruct the tactics of visibility deployed by Wits Pride during the period 2011-2014. The analysis focuses on the promotional T-shirts that were distributed free of charge by the Transformation and Employment Equity Office at the University of the Witwatersrand (hereafter "Wits") in Johannesburg, within the context of the annual Pride march on campus. We believe that these T-shirts are key materialisations of a politics of visibility because they embody the official display through which Wits Pride brands itself. Informed by a queer multimodal approach, the analysis shows that changes over time in the design of Wits Pride T-shirts represent a shift both in what is claimed to be the main goal of campus sexual politics and in the proposed means to achieve such a goal. Before delving into a detailed analysis of the T-shirts, however, we first give some context to Wits Pride, followed by an overview of queer theory and multimodality, both of which constitute the theoretical scaffolding that informs our arguments.

\section{Wits Pride in a South African context}

Pride events have been some of the most powerful strategies of visibility employed by gender and sexual non-normative individuals who momentarily reclaim parts of the urban environment in order to make their quest for equal recognition seen and heard. South Africa is no exception in this regard. The first Pride march took place in Johannesburg's city centre in 1990. Organised under the aegis of the Gay and Lesbian Organisation of the Witwatersrand (GLOW), the march was "a call to all South Africans who are committed to a non-racist, non-sexist, nondiscriminatory democratic future" (De Waal and Manion 2006: 15). The manifesto written for the occasion mobilised a human rights discourse according to which the emancipation for a smaller group of people (lesbian and gay people) is part and parcel of the larger fight for the human rights of all South Africans (see Milani 2015). Walking under the theme of "Unity in the Community", the Pride participants had a specific political and legal goal in mind: the repeal of discriminatory laws against same-sex identities and practices (De Waal and Manion 2006: 13-14). Such a change would be achieved, inter alia, with the inclusion of a clause in the new Constitution that would make discrimination on the grounds of sexual orientation illegal. No doubt, the 1990 Pride march marked a historic moment: it was the first of its kind in South Africa and in Africa; it involved key figures of the anti-apartheid struggle such as Beverly Ditsie, Simon Nkoli, and Edwin Cameron; and it set the precedent for future events of a similar kind.

The enactment of the democratic Constitution in 1995 made real the rights so strongly advocated for in the 1990 manifesto. Since then, Johannesburg Pride has changed its character from a political march in the city's socially mixed centre to a cheerful street parade, first in the wealthy suburb of Rosebank, and subsequently in the exclusive financial hub of Sandton (see Craven (2011) and Milani (2015) for a discussion of the development of Johannesburg Pride). 
The change of names - from "march" to "parade" - and the transfer of locations - from the city centre to the suburbs - could be interpreted as indicators of the increased "lifestylization of sexual politics" (Bell and Binnie 2000; see also Milani 2015) which is a process that involves the collusion between the visibility of non-heterosexual identities on the one hand, and the promotion of specific consumerist practices and the lifestyles associated with them, on the other. As research on consumer culture in South Africa has illustrated (Sonnekus and Van Eeden 2009, Milani and Wolff 2015), this "lifestylization" is not simply about the links between sexuality and social class, but involves complex intersections of race and age as well. It is notable in this respect that, while black activists had been the main leaders in the original Pride marches, white middle-class entrepreneurs increasingly took over the management of the subsequent parades (Craven 2011).

However, it would be wrong to arrive at conclusions about the spatial politics of Pride in Johannesburg based solely on the parade that carries the city's name. In 2004, in the city's largest suburb, Soweto Pride was initiated by the Forum for the Empowerment of Women (FEW) with the aim of countering the racial and social class bias of Johannesburg Pride parades through the provision of "a social space where black lesbian women and the broader LGBTI community and women's rights movement come together, [re]connect and have fun in a safe space" (Soweto Pride Website). Pride politics was further complicated in a series of events set in motion by activist group One in Nine's die-in protest at Johannesburg Pride in 2012 (Milani 2015). A group of black women carrying human-sized figures ran in front of the incoming Pride parade and lay down in the street. A few other women went to stand behind this carpet of bodies, carrying the signs "No cause for celebration" and "Dying for justice". Their aim was to ask the Pride participants to stop and hold a minute's silence in memory of the black lesbians and gender nonnormative individuals killed in South Africa because of their non-compliance with gender and sexual normativities. The failure of the protesters to bring the parade to a halt, and the wellpublicised hostility of the Pride organisers to their protest and subsequent failure to agree on a shared future for Johannesburg Pride, led to a group of activist organisations - including One in Nine - organising Johannesburg People's Pride (JPP) in 2013. JPP is a political march through the streets of Hillbrow, the neighbourhood in the heart of Johannesburg where the first Pride march took place in 1990, and today an area that is feared by many South Africans because of its notoriety with regard to crime.

As sites of political struggle over gender and sexuality, tertiary institutions are no less important spaces than streets. In 2010, Wits Pride was launched by the university's Transformation and Employment Equity Office as a broad-based initiative that aims to create "a non-heterosexist, non-cissexist, non-homophobic and non-transphobic university environment" (Wits Safe Zones website). However, as has been pointed out elsewhere (see e.g. Milani 2013), transformation is something of a catchword at Wits and in South African tertiary education discourse more broadly. According to the website of the Wits Transformation and Employment Equity Office (last accessed 25 August 2015, emphasis added),

there are social, economic, political and cultural imperatives that require both reflection and intervention to redress the inequalities and injustice generated by apartheid on all South Africans. The programmes and projects run by the Transformation and Employment Equity Office are aimed at facilitating this process and, in doing so, to address the impact of these inequalities on life as part of the Wits community. 
At least in its official expression, the transformative approach taken by Wits seems to be very broad and pro-active in levelling out the legacies of the apartheid past. In practice, however, an intersectional approach is often undermined by the urgency of hot-button issues such as race and gender. Wits Vice-Chancellor and Principal Adam Habib's (2015) statement on university transformation, in response to the \#RhodesMustFall movement at the University of Cape Town and its consequences nationwide, presents a progressive administrative programme for racial and gender transformation, but fails to mention sexuality even once. Though good work is being done in this regard (see e.g. Milani 2013), this erasure speaks to the difficulties necessitating the constant reassertion of sexuality as continuous with broader progressive transformation politics.

In summary, visibility is a fraught issue in the contemporary politics of sexuality. In South Africa, Pride events have taken diverse forms which are shaped by the inequalities ensuing from specific intersections of race, class and gender. These power imbalances underpin disagreements on whom and what should be made visible, which have in turn led to the fracturing of Pride into different events. Finally, there is not always a straightforward commitment to visibility, as in the case of Wits, where same-sex desire and gender nonconformance are something of a slippery, absent presence, simultaneously foregrounded and backgrounded (see Fairclough 1995) in transformation discourses and practices.

It is the context of Wits that we bring under investigation in this article, looking in particular at those artefacts that are perhaps the most patent embodiment of the promotion of visibility of sexual and gender non-normative discourses, namely the official T-shirts of Wits Pride. Moved by Phelan's (1997) encouragement to carefully deconstruct the tactics of visibility in the context of LGBTIAQ+ citizenship, we have asked ourselves: Who and what gets represented and therefore becomes foregrounded on Wits Pride T-shirts? This question will be answered with the help of a queer multimodal approach, to which we will now turn.

\section{Queer linguistics and multimodality}

The history of the emergence and development of queer theory and its linguistic sidekick, queer linguistics, has been told many times before (see Jagose 1996; Livia and Hall 1997; Cameron and Kulick 2003; Bucholtz and Hall 2004; Baker 2008; Motschenbacher and Stegu 2013b; Milani 2013, 2014; McCormick, this issue). Suffice it to say that, historically employed as a slur in English-speaking contexts, the word "queer" underwent a process of re-signification in the late 1980s when it began to be used as a positively laden in-group marker, one that sought to overcome the gendered splits created by the categories "gay" and "lesbian", and create instead a broader constituency including anyone who goes against normality, irrespective of sexual (self-)identification. Queer also marked a break with a specific type of politics geared to achieving the recognition of sexual minorities on the grounds of their identities, inaugurating instead a more radical activism that is less concerned with acceptance than with overt challenges to what is considered "normal".

Taking a similarly militant stance, queer theory is a critical enterprise that questions "normative consolidations of sex, gender and sexuality - and that, consequently, is critical of all those versions of identity, community and politics that are believed to evolve 'naturally' from such consolidations" (Jagose 1996: 99). This means that queer theory is geared to deconstructing the processes through which certain sexual identities and practices become normal and normative 
whereas others are reproduced as "deviant". Such an interest in the constitution and reproduction of "regimes of the normal" (Warner 1993: xxvi) has led to increased focus on the more or less subtle ways in which heteronormativity operates, thus showing "those structures, institutions, relations and actions that promote and produce heterosexuality as natural, selfevident, desirable, privileged and necessary" (Cameron and Kulick 2003: 55). The normalisation of heterosexuality and its concomitant normativity, however, are not the only targets of queer critique. Operating like the contrarian, unruly child of academia, one that "rejects a minoritising logic of toleration or simple political interest-representation in favour of a more thorough resistance to regimes of the normal" (Warner 1993: xxvi), queer scholarship has also teased out the processes through which some forms of same-sex identities, desires and practices can be included in the domain of the "normal" (see, in particular, McCormick's article in this issue).

Whether investigating hetero- or homonormativity, a key axiom in queer thinking is that we should be wary of making too easy conflations between sexual desires and practices (a man desiring and/or having sex with another man) on the one hand, and sexual identities (homosexual, gay) on the other. Through labelling, desires and practices are congealed into identities, which, as Butler (1991: 1314) argues, can then be used as "the normalizing categories of oppressive structures or as the rallying points for a liberatory contestation of that very oppression".

Given the role played by language and discourse in normalisation with regard to gender and sexuality, it is quite predictable that queer theory has been defined as "an exercise in discourse analysis. It takes very seriously the signification of words and the power of language" (Giffney 2009: 7). However, we concur with Motschenbacher and Stegu (2013b: 519) that "it is remarkable that Queer Theory and language-focused forms of discourse analysis have, to date, only had limited contact with each other". It is with a view to putting queer theoretical thinking to work on a variety of texts that queer linguistics has emerged as a strand of research that "puts at the forefront of linguistic analysis the regulation of sexuality by hegemonic heterosexuality and the ways in which nonnormative sexualities are negotiated in relation to these regulatory structures" (Bucholtz and Hall 2004: 471).

Analogous to other strands of sociolinguistic and discourse analytical inquiry, what counts as linguistic has been taken as synonymous with spoken or written codes (but see Milani 2013, 2014; Milani and Wolff 2015; McCormick 2013). A recent example of this logocentric bias can be seen in a special issue dedicated to "Queer Approaches to Discourse" (Motschenbacher and Stegu 2013a), where Conversation Analysis, Critical Discourse Analysis and Poststructuralist Discourse Analysis are singled out as "contemporary discourse analytic approaches [that] possess critical agendas that are certainly compatible with Queer-minded work" (Motschenbacher and Stegu 2013b: 528). We do not dispute the importance of these strands of discourse analysis for queer linguistics, but argue that language is inherently multimodal because it "always has to be realised through, and comes in the company of, other semiotic modes" (Kress and van Leeuwen 1998: 186), which entails then that "any form of text analysis which ignores this will not be able to account for all the meanings expressed in texts" (Kress and van Leeuwen 1998: 186). In the same way as other strands of the study of language in society have moved towards multimodality, so we believe that there is much to gain from a similar expansion of queer linguistics if we want to fully capture the different discursive strategies through which gender and sexuality are encoded in contemporary texts (see also Milani 2013). In practice, however, how does one go about analysing multimodality? 
Kress and van Leeuwen (2006) offer a useful toolkit for reading images, based on Halliday's theory of language. According to Halliday (1973), meaning-making systems perform three main functions: ideational, interpersonal and textual (see also Krige and Oostendorp's article in this issue). The ideational function refers to the expression of ideas or abstract thoughts; the interpersonal function indicates the establishment of relationships with audiences that might or might not be present; and the textual function describes the creation of coherent units or messages. How these functions are actually performed in language can be illustrated with examples from spoken and written English. By articulating a specific sequence of sounds or writing certain letters in a particular order, we can express abstract concepts such as 'performativity' or 'nationhood'. Similarly, the second-person singular and plural pronouns "you" in utterances and written sentences enables the creation of a dialogue with an audience of (non-)present hearers or readers. With the help of conjunctions, adverbs and other logical connectors (e.g. "but", "accordingly", "nevertheless"), we can construct coherent and cohesive texts.

These functions, Kress and van Leeuwen would argue, are not restricted to spoken and written languages alone, but are realised by visual images as well, and multimodality captures precisely the dynamic interplay between written language and visual images in performing these functions. Consider, for example, the well-known World War I poster that features a watercolour of Uncle Sam: an old man wearing a top hat with white stars on a blue background, and pointing his index finger at the viewer. The male figure is centred and occupies two-thirds of the available surface of the poster, the remainder of which carries the call "I want YOU for U.S. army" (original emphasis). The colour of the band on the top hat and the stars evoke the US national flag and, by association, the more abstract idea of American nationhood. National affiliation is also expressed linguistically through the acronym "U.S.", used here as a qualifier of the noun "army". So linguistic and visual means together perform an ideational function representing the US national identity through the embodied metonymy of Uncle Sam. As for the interpersonal function, the direct gaze, the pointed finger, and the pronoun "you" (made emphatic by the thick, bold typeface) create a relationship with the viewers, hailing them into an imaginary dialogue with Uncle Sam. Finally, the position of the image at the centre of the poster plays a textual-function role in that it creates a sense of balanced unity. From a queer perspective, this poster does not say anything in particular about sexuality, though the choice of a male figure - Uncle Sam - as a personification of the US is indicative of a gendering process that ties nationalism to men rather than to women (see also Yuval-Davis 1997).

Multimodal expressions of gender and sexuality are evident in the analysis of the posters of the anti-homophobia campaign at Wits entitled "Safe Zones" (Milani 2013; see Figures 1, 2 and 3). On an ideational level, gender and sexual diversity is discursively produced in many of the posters through the use of rainbow colours which, by association, evoke the rainbow flag, one of the most historically poignant icons of the LGBTIAQ+ movement (Milani 2013). The visual rendering of gender and sexual diversity, however, does not seem to be matched by the slogans used in the posters. Consider Figures 1 and 2 below. 


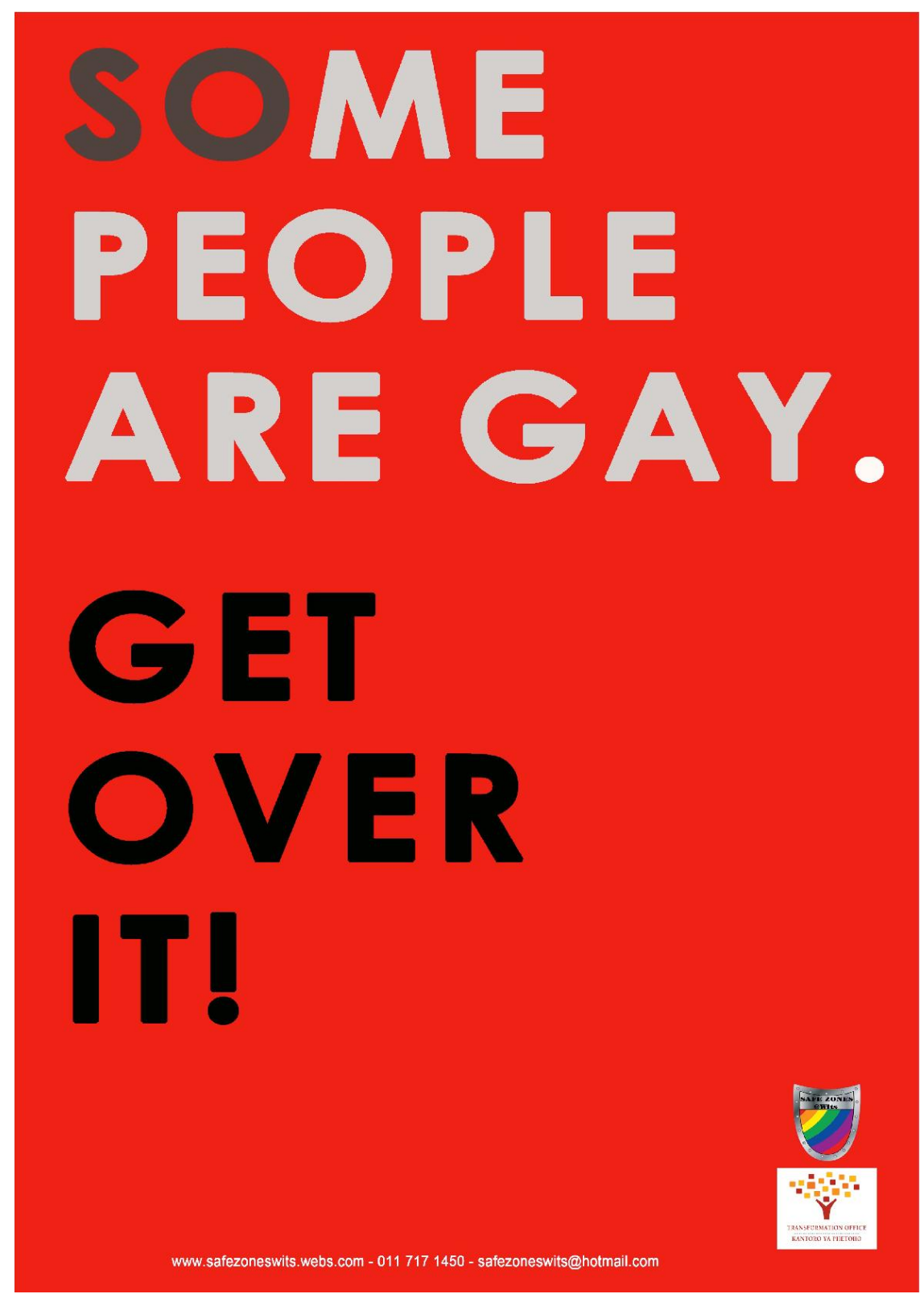

Figure 1. Safe Zones campaign - "Some People Are Gay. Get Over It!"

In Figure 1, while the adjective "gay" is employed as a proud label of self-identification, there is no trace of any label that expresses female homosexuality. By the same token, a foregrounding of male same-sex desire occurs in Figure 2 in the slogan "Bros that like to date their bros are still bros", which makes it clear that the fact that a man is in a relationship with another man does not make him less of a man. Such a slogan could be explained as an attempt to counter dominant societal ideas that view homosexual men as inherently feminine. Furthermore, similar to "men who have sex with men" (MSM), the circumlocution "bros that like to date their bros" is particularly interesting from a queer theoretical point of view because it is an attempt to unsettle too easy conflations between sexual identities ("gay") on the one hand, and sexual desires and practices ("a man dating another man") on the other. It points to the complexity of the lived experiences of sexuality for those who might indeed have romantic and sexual relations with individuals of the same sex but do not identify as gay, lesbian, straight or bisexual. Read together, however, these examples are indicative of a "syntax of hegemony" 
(Billig 1995) through which male homosexual identities are elevated to the status of representative par excellence of LGBT students on campus. This metonymic process is not innocuous but contributes to "marginalising [...] certain sub-groups within the larger group denoted by the acronym LGBT" (Motschenbacher and Stegu 2013b: 524).

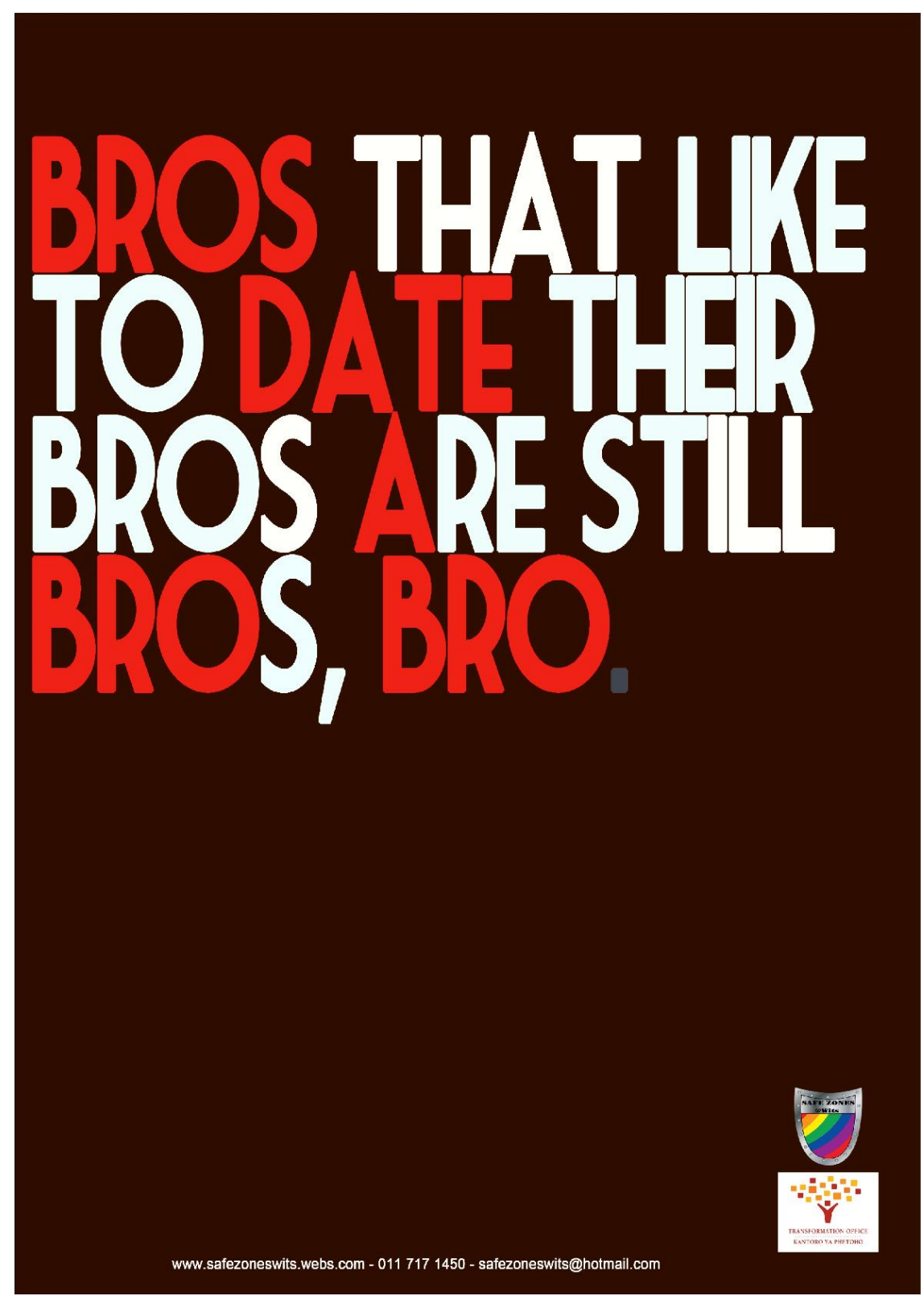

Figure 2. Safe Zones campaign - "Bros That Like To Date Their Bros Are Still Bros, Bro."

On an interpersonal level, the posters establish relationships with the viewer/reader not simply with the help of several linguistic devices such as imperative verbal forms ("Get over it!") and secondperson pronouns ("you"); they also do so through the use of a particular colour palette that combines highly saturated tones of black, red and white. Through a reading that combines Kandinsky's (1977) theory of colour with the views expressed by the designer of the posters, Milani (2013) suggests that red was employed because it catches the attention of the viewer due to its associations with cautionary signs, and the connotations of anger or love. Quoting the words of the designer of the poster, Milani (2013: 227) goes on to observe that "the contrast between black and other colours 
captures the process of 'venting [the feelings of] the community we are speaking about' without downplaying the seriousness of homophobia or evoking associations that are too optimistic". On the basis of this, one could say that "colour was no less important than the messages' propositional content and the particular grammatical choices (i.e. the imperative forms and the pronouns "you") in producing a series of interpellations with which different audiences were "hailed"' (Milani 2013: 227).

What should not be downplayed either are the synesthetic properties of visual choices in producing musical/acoustic effects that contribute to making non-normative discourses about sexuality visually "heard". In this regard, consider Figure 3:

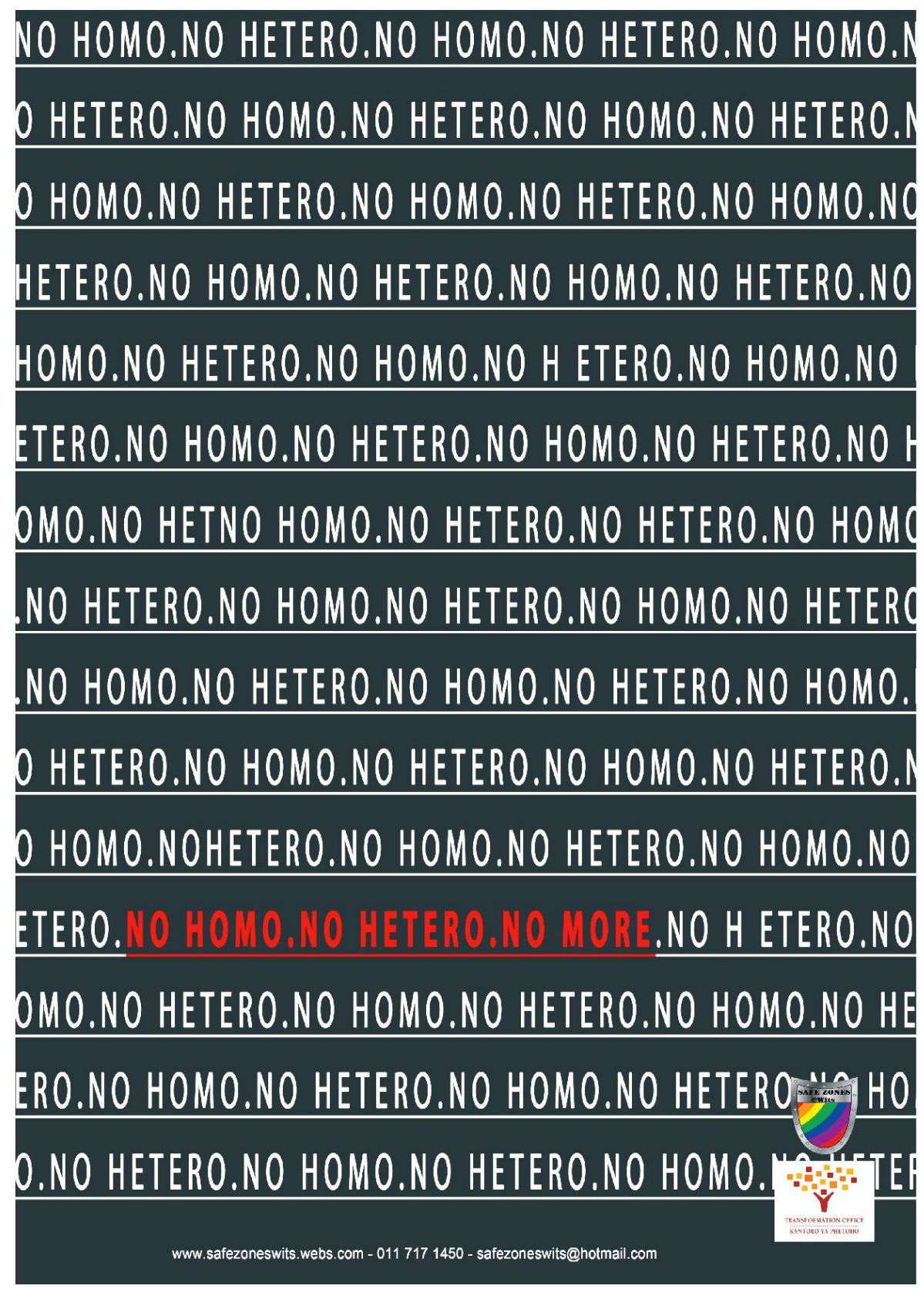

Figure 3. Safe Zones campaign - "No Homo. No Hetero. No More." 
In this poster, the whole space is occupied by the repetition of the sequence "no homo. no hetero." in small, white, underlined capitals, which is interrupted once by "no homo. no hetero. no more." in equally small, underlined capital letters, albeit in red. In terms of content, the incitement to negate both "homo" and "hetero" indicates an attempt to reject sexual dichotomies, and, by implication, to embrace sexuality as a spectrum. Typographically, the repetition of the two word pairs "no homo" and "no hetero", neatly separated by a full stop, produces the acoustic effect of a two-beat rhythm pattern which is disturbed only once by the third pair "no more".

Whether as a result of visual choices or message contents, or both, audiences were indeed interpellated on an emotional level. A week after the launch of the campaign, one third of the posters had either been damaged or had disappeared. While contempt, anger or disgust may have motivated the damaging of the posters, appreciation and admiration may account for their removal, with staff and students carefully detaching them from the public spaces of university corridors and noticeboards with a view to hanging them up in the more private spaces of their offices and/or bedrooms.

On a textual level, the use of the combination of a limited number of colours - typically black for the background, and white for the slogans, interspersed with red and the rainbow contributed to creating a sense of uniformity and cohesiveness across the different posters.

Overall, the multimodal analysis of the Safe Zones campaign is of queer relevance insofar as it illustrates how the silence about non-normative genders and sexualities in Wits official discourses and spaces is momentarily disrupted by multimodal semiotic artefacts - the posters - that make same-sex identities and desires clearly seen and "heard". In doing so, however, the campaign also carries some tensions between, on the one hand, the reliance on certain sexual and gender identity categories (but not others) as instruments for the empowerment of non-normative gender and sexuality on campus, and, on the other, the deployment of anti-identitarian discourses that seek to avoid identity categories altogether. As we illustrate in the next section, similar tensions also characterise the semiotic choices in the design of Wits Pride T-shirts.

\section{Wits Pride T-shirts}

We mentioned earlier in the discussion of Pride events that there is some controversy about the role played by visibility in securing gender and sexual rights. Whilst some social actors, like Justice Cameron, unreservedly espouse the importance of making oneself seen and thus recognisable as a sexual being in public spaces, others, like Phelan, critically interrogate which specific aspects are highlighted or downplayed for political purposes through linguistic and visual choices made on placards and T-shirts during Pride marches. Although Wits Pride officially started in 2010, branded T-shirts were only used from 2011 onwards. As the official report of the Transformation and Employment Equity Office states, they were part of a marketing strategy "to create awareness" (Kotze and White 2013: 20) and, like all institutional branding initiatives, they were also geared to creating an increased sense of belonging for students and staff to Wits.

\section{1 "It's for All of Us" (2011)}

As can be seen in Figure 4, the colour black dominates the $2011 \mathrm{~T}$-shirt. While the front of the $\mathrm{T}$-shirt is free from any text, the back carries the quote "SHHHH, NOBODY KNOWS I'M 
GAY", written in thick white capital letters above the Wits Pride logo - two lips blowing a vuvuzela - and the university crest, both also in white.

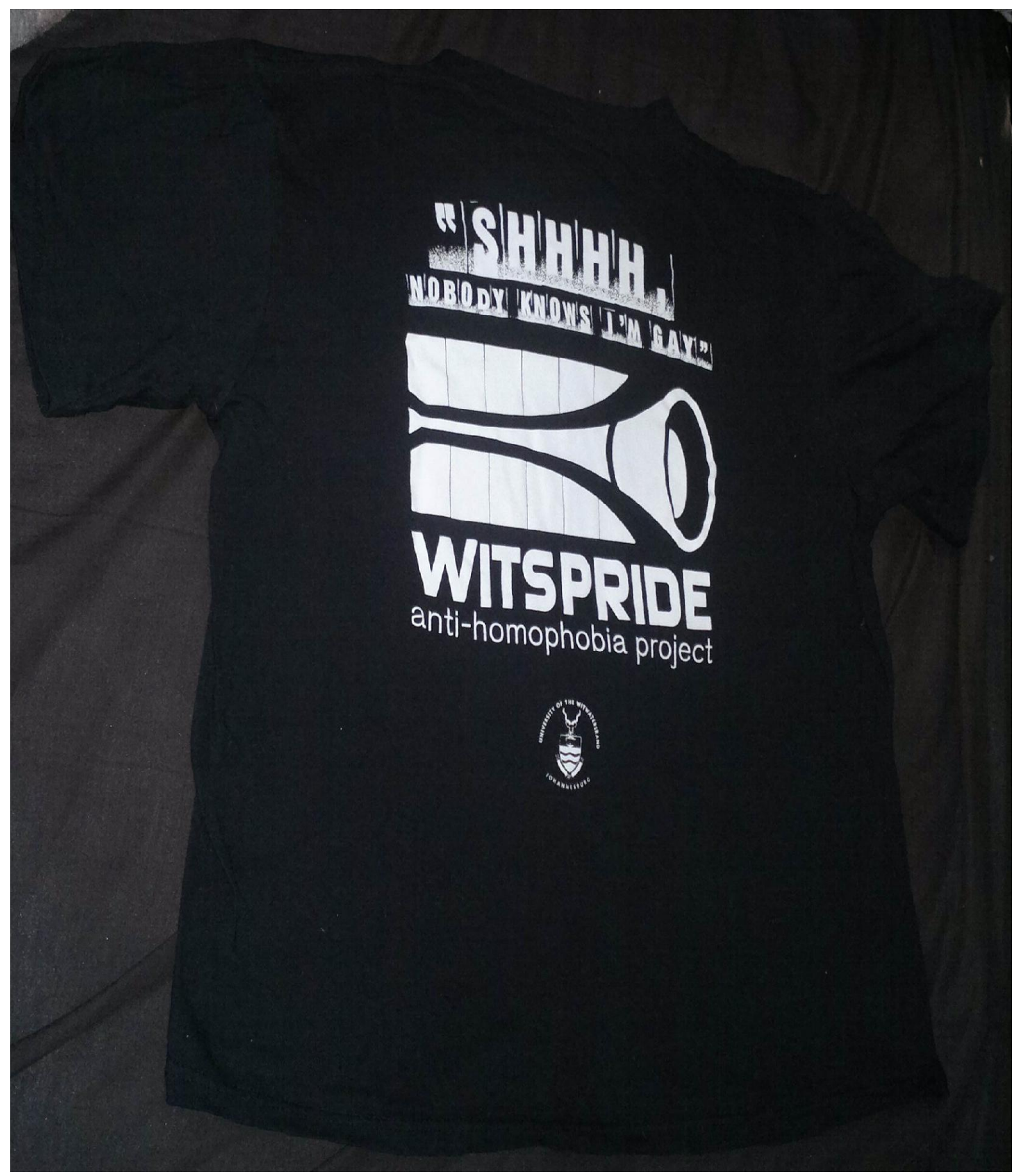

Figure 4. The "It's For All Of Us" design

We know that "white and black have an antithetical relation to each other; they are polarised opposites, each at one end of the scale from extreme light to deepest darkness" (Milani 2013: 227). So the use of opposite colours creates a stark contrast that makes linguistic and visual elements stick out of the otherwise monotonous background. The contrast, however, is not only chromatic, but also involves the creation of conflicting acoustic and emotional effects. 
In a collection of highly personal and subjective reflections on colour, the Russian painter Wassily Kandinsky observes that "[a] totally dead silence, a silence with no possibilities, has the inner harmony of black. [...] The silence of black is the silence of death" (Kandinsky 1977: 45). In his view, white is also a signifier of silence, one though that is "pregnant with possibilities. White has the appeal of the nothingness that is before birth, of the world in the ice age" (1977: 45). These distinctions about chromatic meanings have regrettably been projected onto race, and have contributed to the creation of a powerful, discriminatory, racist order in which white people claim that there is no possibility in blackness. As film studies scholar Richard Dyer explains,

[p]ower in contemporary society habitually passes itself off as embodied in the normal as opposed to the superior. This is common to all forms of power, but it works in a peculiarly seductive way with whiteness, because of the way it seems rooted, in common-sense thought, in things other than ethnic difference [...] Thus it is said (even in liberal textbooks) that there are inevitable associations of white with light and therefore safety, and black with dark and therefore danger, and that this explains racism (whereas one might well argue about the safety of the cover of darkness, and the danger of exposure to the light); again, and with more justice, people point to the Judaeo-Christian use of white and black to symbolize good and evil, as carried still in such expressions as "a black mark," "white magic," "to blacken the character" and so on.

(Dyer 1988: 45)

The complexity of racial politics aside, the colour black on the T-shirt could symbolise the silence that results from the well-established view that sexuality is a private matter and therefore should not be talked about in public spaces. White, instead, is the colour for breaking the silence. These theoretically-driven conclusions, based on a highly speculative theory of colour, are supported by the fact that the relationship between silence and noise also emerges from the analysis of the linguistic and visual elements on the T-shirt.

The quotation marks are typographical devices that suggest the voice of an imaginary speaker, one that, through the interjection "SHHHH", invites potential audiences to discretion and concealment. Such an incitement to whispered secrecy is countered by the representation of the vuvuzela, which evokes the powerful sound of the South African horn made famous worldwide thanks to the FIFA World Cup in 2010. So the multimodal juxtaposition of linguistic and visual elements creates diametrically opposite auditory effects: silence and noise. This acoustic opposition, in turn, recurs on an affective level. While the sound of the vuvuzela trumpets the pride that imbues the anti-homophobia initiative, the hushed tone of voice accentuates the nearly shameful character of the speaker's confession. Moreover, the position of this multisemiotic arrangement on the back, rather than on the front of the T-shirt, is itself semiotically relevant; it indicates an ambivalent attitude to the visibility of same-sex identity - not a proud gesture of self-identification to be carried on one's chest, but an "open secret" on one's back only to be revealed when turning around. This position notwithstanding, the reticence in divulging one's sexual identity is paradoxically jeopardised by its very pronouncement. Whether worn on the front or the back of one's body, the very act of saying "nobody knows that I am gay" is ultimately a performative speech act through which the speaker embraces a sexual identity category ("gay") and "comes out" for an audience (see McCormick (2013) for a critical analysis of coming-out discourses in South Africa). 
Read together, multimodal means conjure up an ambiguous pattern of affective and acoustic oppositions in which shameful secrecy about one's sense of sexual selfhood co-exists with the loud-and-proud public display thereof. Considering that the theme for Wits Pride that year was "It's for All of Us", the T-shirt design does not simply embody a clear statement that the march was for everyone, including those who are not openly out, but is also an encouragement for them to come out in order to fight against homophobia. The pronominal expression "all of us" is a linguistic gesture to an all-encompassing "imagined community" (Anderson 1991) of Wits students and staff, irrespective of labels of self-identification. Such rhetoric of inclusion is at odds though with the rather narrow choice of "gay" as the main identity label, among the many available ones, through which to represent gender and sexual non-normativities on Wits Pride T-shirts. Similar to what has been observed elsewhere (e.g. Milani 2013) in relation to the Safe Zones initiative which started in 2011, the use of the word "gay" here could be another example that testifies to the work of a "syntax of hegemony" (Billig 1995) within sexual transformation discourses at Wits. Analogous to the ways in which metonymy operates as a figure of speech, we can see how an apparently mundane linguistic choice ("gay") gives visibility to a specific gendered section of the larger LGBTIAQ+ group, and thus elevates it as the representative par excellence of that very group.

\section{2 "Stop Sexual Apartheid" (2012)}

As with the 2011 T-shirt, the design on the T-shirt in 2012 (see Figure 5 below) is printed on the back, yet, as will be analysed and explained in this sub-section, very different semiotic choices were made this time around.

As is evident in Figure 5, the vuvuzela takes centre stage in the logo, accompanied by the captions "WITSPRIDE" in bold capitals, and "anti-homophobia project" in thinner, smaller, lower case characters. This rather eye-catching multimodal arrangement is positioned above the slogan for that year's Wits Pride, "STOP SEXUAL APARTHEID", which is visually less prominent due to the smaller size of its capital letters. Such a vertical arrangement is meaningful, according to Kress and van Leeuwen (2006), because different information values can be realised by the relative position of different elements vis-à-vis the vertical axis so that one can distinguish between a "top" and a "bottom" section. These, in turn, correspond to what Kress and van Leeuwen (2006) call the "ideal" - the domain of "what might be" - and the "real" which is the reality of "what is". Drawing upon Lakoff and Johnson's (1980) metaphor theory, Chandler (2007) suggests that the compositional distinction between upper and lower areas in a semiotic space carries further associations, which are the result of the metaphorical meanings of "up" and "down" in English language use:

$[U] p$ is associated with goodness, virtue, happiness, consciousness, health, life, the future, high status, having control or power, and with rationality, while down is associated with badness, depravity, sickness, death, low status, being subject to control or power, and with emotion.

(Chandler 2007: 112, original emphasis) 


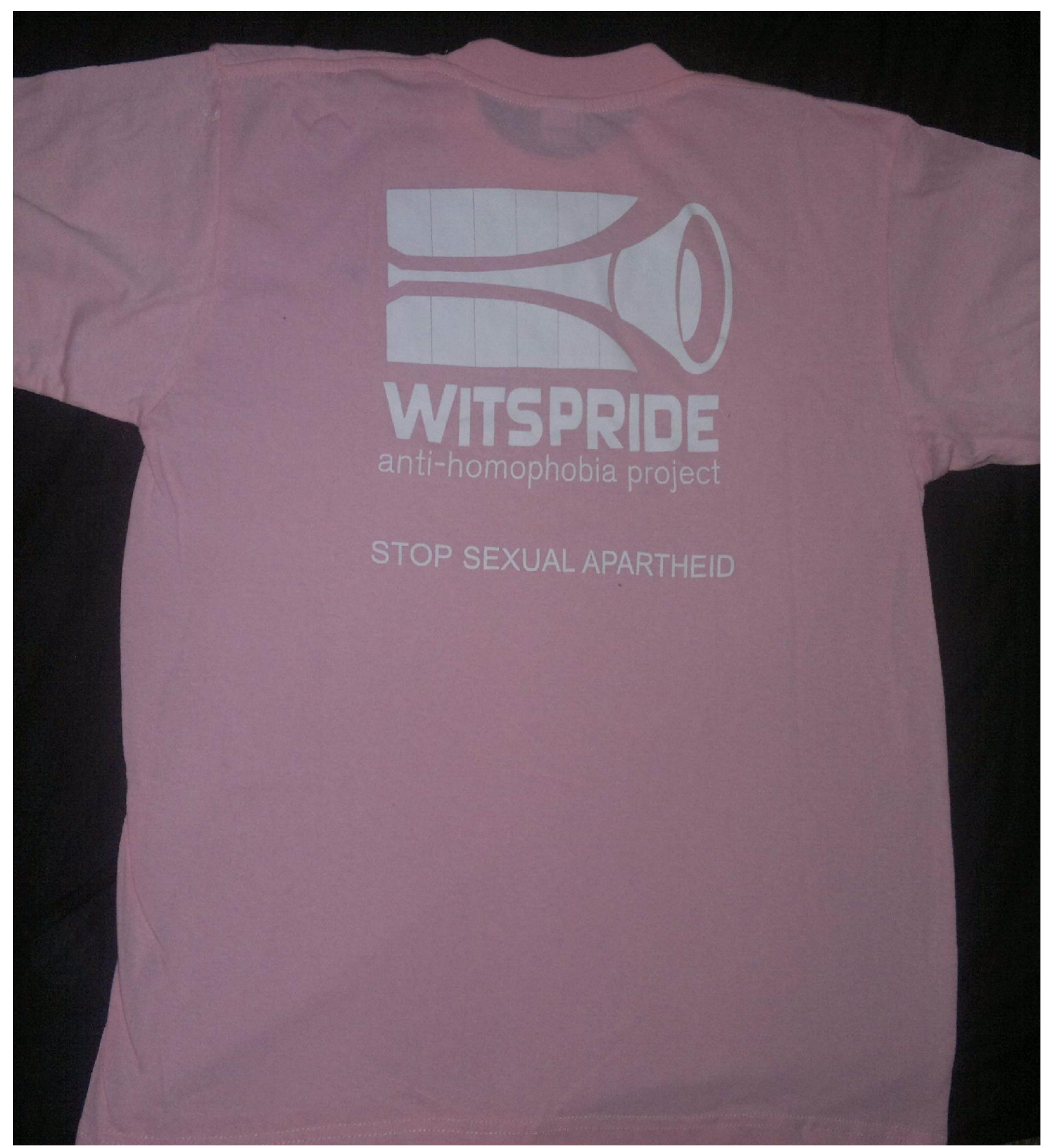

Figure 5. The "Stop Sexual Apartheid" design

Needless to say, the distinctions between up and down, top and bottom, ideal and real, and their respective connotations, are not always applicable to all multimodal compositions. This caveat notwithstanding, it is interesting to observe in Figure 5 how the position of the words "PRIDE" and "anti-homophobia" in the realm of the upper section of the "ideal" (Kress and van Leeuwen 2006) could be interpreted as indications that sexual equality and respect for sexual diversity have not yet been achieved, but are aims for an ideal future. These aspirational goals are in contrast with the "real" (Kress and van Leeuwen 2006) expressed in the bottom part of the design. Here, the verbal form "STOP" in the imperative mood is underpinned by two presuppositions (see Fairclough 2003: 55): (i) a propositional assumption that an event, process 
or phenomenon is still ongoing, and (ii) an evaluative assumption that such an event, process or phenomenon is negatively laden, and therefore should be ended. These presuppositions, together with the placement of the imperative sentence in the lower part of the design, suggest that "sexual apartheid" is not over and is, in fact, a thriving present condition. In this context, the choice of the Afrikaans word "apartheid" ('separation') is emotionally charged; it evokes years of state-sanctioned oppression on the grounds of race perpetrated by a numerical minority of white people against the majority of black South Africans. To judge from the text of the slogan only, it is unclear whether "SEXUAL APARTHEID" refers to inequalities based on the separation between privileged heterosexuality and oppressed homosexuality, or to racially discriminatory trends between so-called "queer peers" (McElhinny 2002). The latter interpretation is supported by a cursory overview of other informational material for Wits Pride 2012, which features, inter alia, a picture of two young men - one white and one Indian - in an affectionate embrace.

In terms of colour choice, the white text against a pink background creates some degree of contrast, although in a less striking way than the black/white combination of the previous year (see Figure 4). While the white letters on the $2011 \mathrm{~T}$-shirt were typographic attempts to break the silence of homophobia, the pink background of the 2012 T-shirt mobilises a well-established carrier of gender and sexual identity meanings. Throughout the $20^{\text {th }}$ century, dominant discourses and practices have contributed to the sedimentation of a link between pink, women and femininity (Koller 2008). This gendered association has been carried over to sexual identity as a result of the dominant belief in the gender inappropriateness of sexual non-normative individuals. According to this view, gay men are assumed to be feminine and lesbian women masculine. As Koller (2008: 409) notes in a visual semiotic history of the colour pink, "[o]ne of the most disturbing manifestations of this discourse was gay male prisoners of Nazi concentration camps being forced to wear pink triangles (while lesbians were branded 'asocial' [and had to wear black triangles])".

Like the word "queer", the pink triangle was later reclaimed as a semiotic means of sexual selfaffirmation and, together with the rainbow flag, became an icon of gay liberation. This is not to say that the colour pink today univocally carries connotations of struggles for the emancipation of sexual minorities. On the contrary, Koller's (2008) work illustrates the ambiguous and contradictory functions of pink in contemporary visual culture, where it is employed as a marker of conventional femininity, a tongue-in-cheek tool for the performance of male effeminacy, and a proud symbol of LGBTIAQ+ history. All of these meanings could also be drawn upon and activated by different people wearing or looking at this Wits Pride T-shirt in the context of South Africa. Without downplaying this rich polysemy, the violent discrimination linguistically encoded by the word "apartheid" may find in the intertextual reference to the pink triangle a chromatic counterpart that evokes the vicious persecutions specifically targeting homosexual men in Nazi Germany. Against this backdrop, it is quite unsurprising that one of the organisers of subsequent Wits Prides, Ella Kotze, expressed a level of discomfort with the colour choice in 2012. In an interview, she said that she "felt like pink symbolically tied the whole thing to gay men". Like the word "gay" on the 2011 T-shirt, the colour pink could be interpreted as visual metonymy that highlights the male-only "G-section" of the LGBTIAQ+ community, and thus erases the gendered and sexual heterogeneity of the people within such community. 


\section{3 "Being Me" (2013)}

Unlike in the previous two years, the 2013 Wits Pride T-shirt (see Figure 6) has the design printed on the front, rather than on the back.

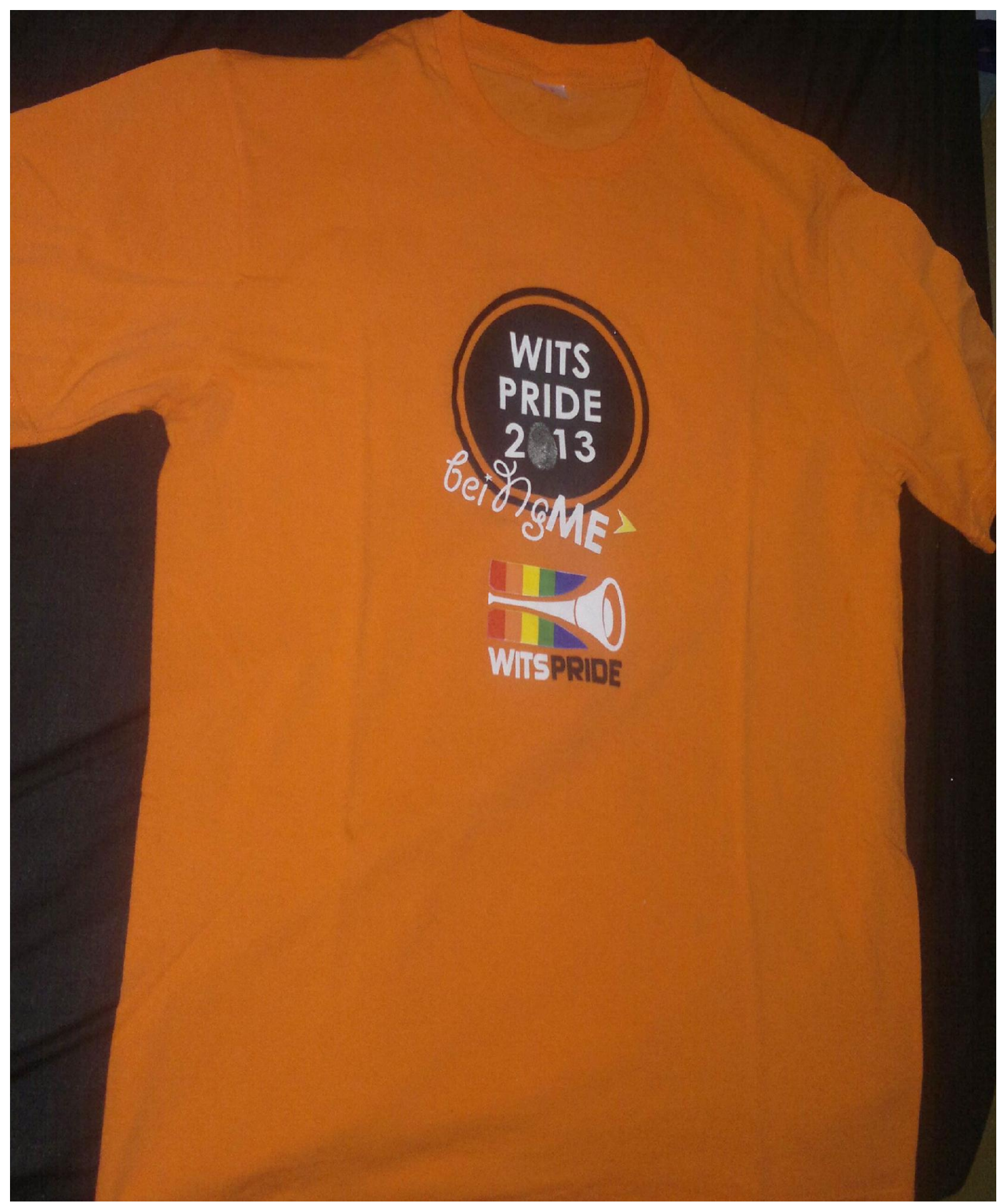

Figure 6. The "Being Me" design 
The design is compositionally more complex than its predecessors, being multicoloured and including the year of the event. As for colour choice, a highly saturated orange dominates the background. In this regard, the coordinator of Wits Pride 2013, Ella Kotze says: "I did not want to use any colour that was symbolic of any specific part of 'LGBTI'. I knew that orange was symbolic of optimism and rejuvenation, so I thought that would be a good choice on a symbolic level". Against the orange background are black, white and rainbow elements. Such a colour assemblage creates, once again, a strong, eye-catching chromatic contrast.

Analogous to the two previous designs, the text "WITS PRIDE 2013" is in bold, white capitals, but this time is superimposed on a solid black circle, itself surrounded by a larger yet thinner concentric black ring. A fingerprint substitutes the zero in " 2013 ", and the slogan for the year, "being ME", functions as an oblique signature that crosses the bottom part of the circular arrangement. Beneath this part of the design is the Wits Pride logo, a horizontal white vuvuzela this time flanked at the top and bottom by a rainbow flag. What is notable here, compared to previous years, is the absence of the sub-title "anti-homophobia project" from the logo.

To begin with, the use of a round shape to represent Wits Pride 2013 is not dissimilar to the choice of geometrical elements made in the material for the Safe Zones anti-homophobia campaign (Milani 2013). As Kress and van Leeuwen (2006) point out, drawing upon the reflections of the Dutch artist Piet Mondrian,

[b]asic geometrical shapes have always been a source of fascination, even of religious awe. Our scientific age is no exception. Circles, squares and triangles have been regarded as pure, quasi-scientific 'atoms' of the visible world, 'a pure manifestation of the elements', the 'universal-as-the-mathematical'.

(Kress and van Leeuwen 2006: 53)

The authors also clarify that angular shapes are typically associated with inorganic matter and technology, and therefore with rationality and order; circular shapes, in contrast, are perceived as symbolising the organic world of nature, together with "endlessness, warmth, and protection" (Dondis 1973: 44). In light of these observations, we suggest that the concentric round shapes in the 2013 Wits Pride T-shirt design convey a sense of protection - a safe, round space defended by a circular fence where one can be oneself.

This sense of unique selfhood is visually represented on the T-shirt by a fingerprint. Fingerprints are understood to be unique and, because of that, are used to identify people and their movements. Here, the fingerprint is employed as an icon of distinctive self-identification, and resonates visually with the first-person personal pronoun "ME" in bold capitals (which, in writing and email etiquette, symbolise emphasis, loud speech or shouting). Individuality is also conveyed typographically by the choice of a cursive font for the verb "being", which is reminiscent of a handwritten signature - another well-established marker of unique selfidentification. The choice of a star instead of the usual dot on the "i" in "being" further implies a personal touch. All in all, visual and linguistic elements are marshalled together to produce individuality and authenticity.

The specific traits such uniqueness takes the form(s) of are, of course, not specified on the Tshirt. Nowhere are sexual identities expressed linguistically, like "gay" in the 2011 design, nor is the adjective "sexual" present, like in the 2012 design. However, the Wits Pride project team 
clearly stated in a report that they chose the "being ME" slogan in order to encourage university staff and students to "explore what it meant to be themselves in the context of gender and sexuality" (Kotze and White 2013: 2, emphasis added). Obviously, the word "pride", repeated twice, and the rainbow colours are historical markers of LGBTIAQ+. The inclination of the slogan "being ME" might also be significant in this regard because it is not aligned with the other elements in the design: it is not straight. Colloquially, "straight" is synonymous with "heterosexual", so the obliquely-angled text may be a visual strategy through which to convey a sense of selfhood that is not heterosexual. Moreover, the yellow symbol $>$ is like a vector that enhances the sense of movement created by the inclination of the slogan. As such, it is a visual device that boosts the sense of dynamic process linguistically conveyed through the gerund "being". As Ella Kotze noted, "[t]here's something about leaving it open, allowing shifts, in the [slogan] 'being ME', which I liked at the time - who you are does not need to be static; you can move through the whole range of queer expressions and that is fine". So this visual device is not just a "signpost" that visually highlights the slogan, as Kotze suggests, but could also be interpreted as an arrow indicating a way "forward", namely the development of a gender and sexual non-normative, unique "me".

Finally, the absence of the sub-title "anti-homophobia project" from the 2013 Wits Pride logo might be indicative of a change of the scope of Wits Pride beyond a specific focus on the fight against discrimination on the grounds of sexuality, towards a broader gender and sexual transformation that involves transgender, queer, asexual, intersex and gender non-conforming individuals, as well as other axes of social categorisation. This is an expansion that, as we will see in the next section, was developed further in 2014.

\section{4 “All Oppression is Connected" (2014)}

In 2013, Wits Pride held a competition for which students were invited to design a T-shirt around the theme of "Being Me". The contest was won by an architecture student, Jason Temlett, with the design "Me and Everything I am", which was then printed on all Wits Pride T-shirts for that year. As can be seen in Figures 7 and 8, this is the first time the T-shirts have featured both front and back designs. It is also the first time that the logo of the Wits Transformation and Employment Office is featured.

The central section of the T-shirt's front design is occupied by a multicoloured, nearly kaleidoscopic, speech bubble that, as though emanating from the chest of the wearer, declares "ALL OPPRESSION IS CONNECTED”. As the designer explained in an interview,

the shape is informed by the Rainbow Flag, with vertical stripes made up of different coloured chevrons. The colours within the pattern come not only from the rainbow, but a diverse variety of backgrounds not limiting itself solely to the LGBTIA community, but rather allowing the wearer to be able to express their pride in whoever they choose to be recognised as.

(Rowland 2013) 


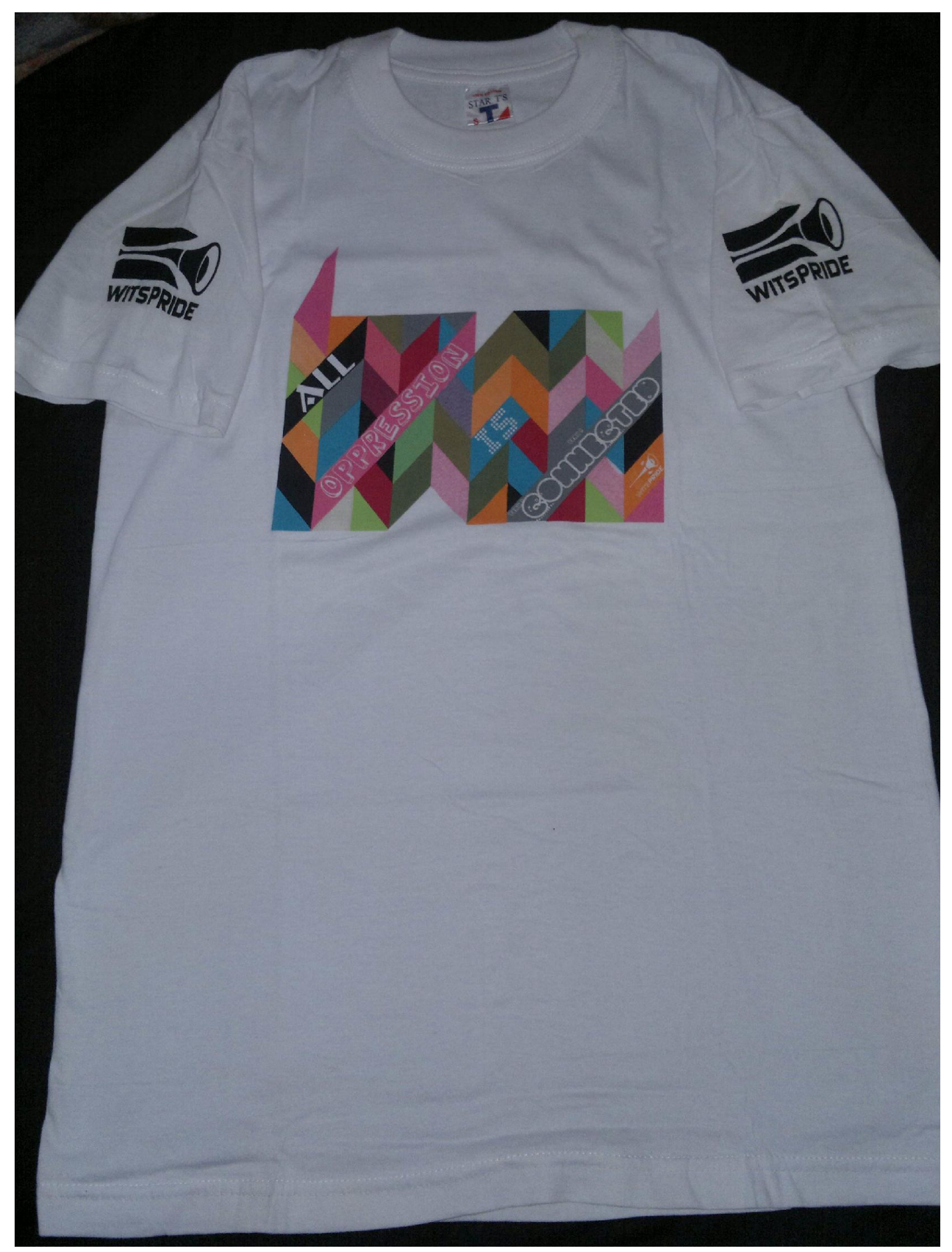

Figure 7. "All Oppression Is Connected" - Front design 


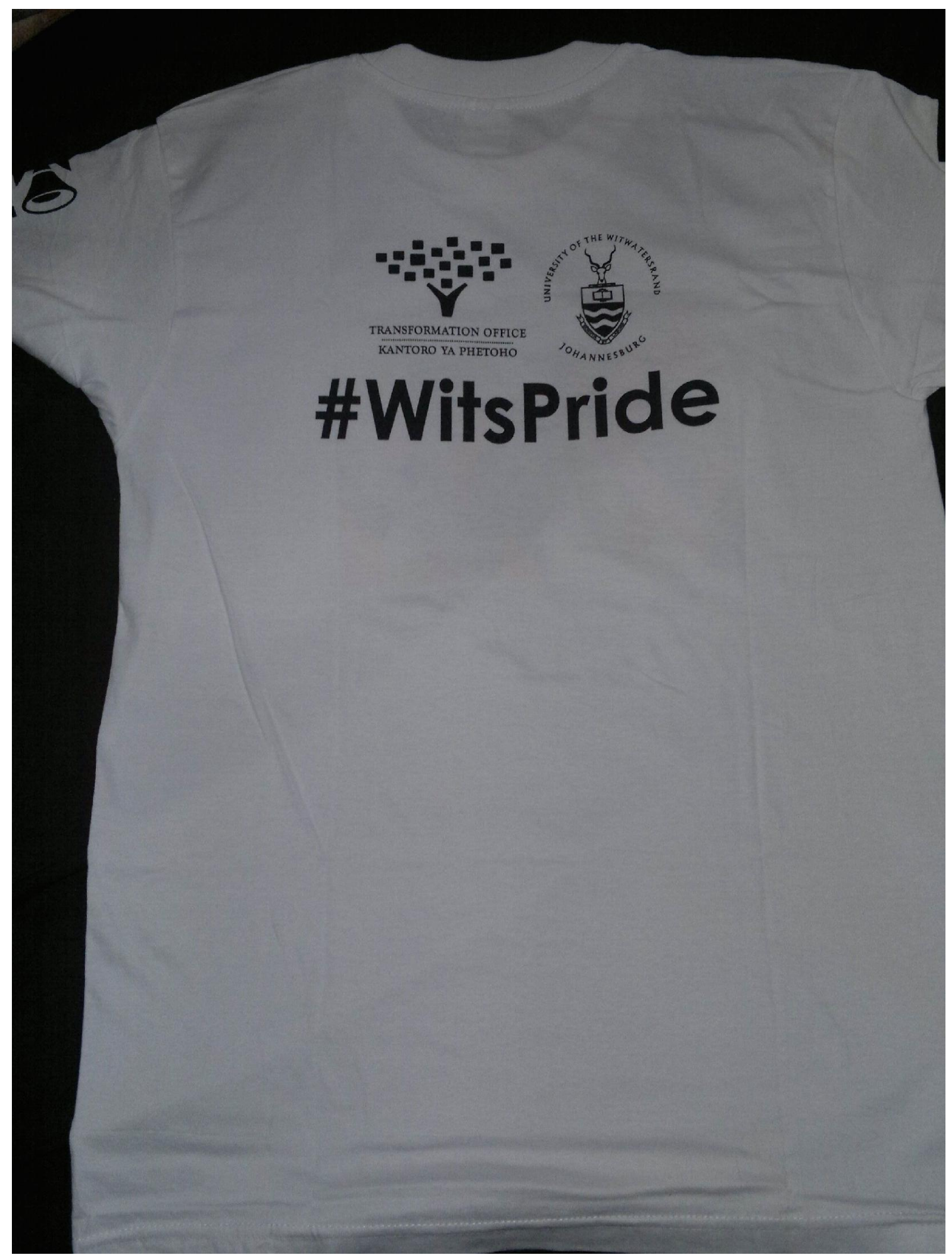

Figure 8. "All Oppression Is Connected" - Back design

Compared to previous years, it is noticeable how the Wits Pride logo in this design has been moved from the back or the front of the T-shirt to the sleeves, although there is a very small, 
white silhouette of the vuvuzela from this logo on an orange section in the bottom right corner of the coloured block of chevrons. The small size of the vuvuzela on the front of the T-shirt, together with the repositioning of the Wits Pride logo to the sleeves, are semiotic choices of backgrounding which may indicate a move from a politics of visibility that single-handedly focuses on sexuality towards a broader transformative project that seeks to appeal to anyone who is against discrimination.

That the fight against all forms of discrimination is a key issue of university transformation is reinforced at the back of the T-shirt by the appearance of the Wits Transformation and Employment Office's bilingual logo, with "Transformation Office" in English placed above its Sesotho equivalent "Kantoro ya Phetoho". In this respect, it should be noted that in 2003 Wits adopted a policy through which it "commits itself to multilingualism and the phased development of Sesotho as a language that can be used as a medium of instruction together with English" (University of the Witwatersrand 2003: 5). The Wits Transformation logo is one of the very few semiotic artefacts in the linguistic landscape of the university that reflects this policy, and therefore should be given some degree of credit for promoting bilingualism on campus (see also Kadenge (2015) for a linguistic landscape analysis of Wits campus). On the other hand, the placement of the Sesotho text beneath the English text shows that English is given visual priority. Moreover, it is quite surprising that, throughout the years, all slogans on Wits Pride T-shirts have been in English. While such language choice is indicative of macroideologies that view English as the main lingua franca in South Africa, it is nonetheless remarkable that, in doing so, Wits Pride has been complicit in erasing the multilingual reality of Wits campus and South Africa more generally.

Lastly, the hash sign \# in front of "WitsPride" is a semiotic device that establishes an interpersonal relation with potential audiences of the Pride event by inviting them to use major social media platforms, particularly Twitter, which popularised the style of placing a hash sign before an important phrase, thus creating a "hashtag". Such a semiotic choice is the reflection of the stronger online presence of Wits Pride since 2013 (Kotze and White 2013). The hash sign not only alerts people watching or participating in the Pride march to the fact that they can tweet about the event using the specific hashtag \#WitsPride, it is also an indication of the increasing blurring of the boundaries between "material" and "virtual" spaces which, in turn, leads to the questioning of the applicability of these very labels. The virtual/material connection also points to the importance of acting in a variety of different spaces against discrimination for social transformation.

\section{Concluding remarks}

Since 2011, the Transformation and Employment Equity Office at Wits has freely distributed T-shirts to staff and students who then wore them during the yearly Wits Pride march. The Tshirts were tools of a politics of visibility that seeks to momentarily (re)shape the otherwise heteronormative university spaces by making non-normative genders and sexualities seen and "heard". However, the tactics through which this visibility was made ready-to-wear on Wits Pride T-shirts were not uniform, but instead took very different guises throughout the years. With the help of a queer multimodal analysis that takes a critical stance on which gender and sexual identity categories are mobilised (or not), the analysis showed an alternation between foregrounding sexual identities ("gay") and individuality ("being me") on the one hand, and highlighting structural conditions and processes ("apartheid" and "oppression") on the other. If 
we were to imagine that each T-shirt is a corporeal embodiment of Wits Pride, this body has changed shape considerably over the last four years. It has morphed from performing a gay man who is supposedly ashamed of voicing his sexual identity, to enacting a more camp though still masculine "figure of personhood" (Agha 2005) that loudly urges to counter racial division within same-sex desire. This gendered character, in turn, has changed into a more multifaceted individual who proudly carries their gender and sexual uniqueness, and more recently, has transformed again into an activist who, in the fight against the complex intersections that underpin discrimination, is perhaps a little reluctant to foreground gender and sexuality at all.

\section{Acknowledgments}

We want to thank the Wits Transformation and Employment Equity Office - in particular Tish White, Cameron Anzio Jacobs, and Ella Kotze - for their unconditional generosity in sharing with us their views on Wits Pride. We are also indebted to Gilles Baro and Scott Burnett for their insightful comments on a previous version of this article. Finally, the first author wants to thank Rickard Jonsson (Stockholm University) for offering a stimulating academic environment that enabled the completion of this article.

\section{References}

Agha, A. 2005. Voicing, footing, enregisterment. Journal of Linguistic Anthropology 15(1): 38-59.

Anderson, B. 1991. Imagined communities: Reflections on the origins and spread of nationalism. London: Verso.

Baker, P. 2008. Sexed texts: Language, gender and sexuality. London: Equinox.

Bell, D. and J. Binnie. 2000. The sexual citizen: Queer politics and beyond. London: Polity.

Billig, M. 1995. Banal nationalism. Thousand Oaks, CA: Sage.

Bucholtz, M. and K. Hall. 2004. Theorizing identity in language and sexuality research. Language in Society 33(4): 469-516.

Butler, J. 1991. Imitation and gender insubordination. In D. Fuss (Ed.) Inside/Out: Lesbian theories, gay theories. New York: Routledge. pp. 13-31.

Cameron, D. and D. Kulick. 2003. Language and sexuality. Cambridge: Cambridge University Press.

Chandler, D. 2007. Semiotics: The basics. London: Routledge.

Craven, E. 2011. Racial Identity and Racism in the Gay and Lesbian Community in PostApartheid South Africa. Unpublished Master's thesis, University of the Witwatersrand.

De Waal, A. and A. Manion. 2006. Pride: Protest and celebration. Johannesburg: Fanele. 
Dondis, D.A. 1973. Primer of visual literacy. Boston: MIT Press.

Dyer, R. 1988. White. Screen 29(4): 44-65.

Fairclough, N. 1995. Media discourse. London: Arnold.

Fairclough N. 2003. Analysing discourse: Textual analysis for social research. London: Routledge.

Giffney, N. 2009. Introduction: The 'q' word. In N. Giffney (Ed.) The Ashgate research companion to queer theory. Aldershot: Ashgate. pp. 1-13.

Habib, A. 21 May 2015. Opening the conversation: Accelerating transformation for an inclusive and competitive Wits. Available online: http://blogs.wits.ac.za/vc/2015/05/21/ opening-the-conversation-accelerating-transformation-for-an-inclusive-and-competitive-wits/ (Accessed 8 September 2015).

Halliday, M.A.K. Explorations in the functions of language. London: Arnold.

Jagose, A. 1996. Queer theory: An introduction. New York: New York University Press.

Kadenge, M. 2015. 'Where art thou Sesotho?' Exploring the linguistic landscape of Wits University. Per Linguam 31(1): 30-45.

Kandinsky, W. 1977. Concerning the spiritual in art. New York: Dover Publications.

Koller, V. 2008. 'Not just a colour': Pink as a gender and sexuality marker in visual communication. Visual Communication 7(4): 395-423.

Kotze, E. 19 August 2015. Online interview.

Kotze, E. and T. White. 2013. Wits Pride 2010-2013 project report. Johannesburg: Wits Transformation and Employment Equity Office.

Kress, G. and T. van Leeuwen. 1998. Front pages: (The critical) analysis of newspaper layout. In A. Bell and P. Garrett (Eds.) Approaches to media discourse. Oxford: Blackwell. pp. 186-219.

Kress, G. and T. van Leeuwen. 2006. Reading images: The grammar of visual design. $2^{\text {nd }}$ edition. London: Routledge.

Krige, J. and M. Oostendorp. 2015. "Too late for tears, dear sister": Constructing victims and perpetrators of rape in the advice column 'Dear Dolly' from 1984 to 2004. Stellenbosch Papers in Linguistics Plus 46: 1-17.

Lakoff, G. and M. Johnson. 1980. Metaphors we live by. Chicago: University of Chicago Press.

Livia, A. and K. Hall. 1997. 'It's a girl!' Bringing performativity back to linguistics. In A. Livia and K. Hall (Eds.) Queerly phrased: Language, gender and sexuality. Oxford: Oxford University Press. pp. 3-18. 
Mabula, R. 13 August 2015. Visibility will enhance sexual equality. Available online: http://www.wits.ac.za/newsroom/newsitems/201508/27070/news item 27070.html (Accessed 25 August 2015).

McCormick, T.L. 2013. Queering discourses of coming out in South Africa. Stellenbosch Papers in Linguistics Plus 42: 127-148.

McCormick, T.L. 2015. A critical engagement? Analysing same-sex marriage discourses in 'To Have and to Hold: The Making of Same-Sex Marriage in South Africa' (2008) - A queer perspective. Stellenbosch Papers in Linguistics Plus 46: 105-126.

McElhinny, B. 2002. Language, sexuality and political economy. In K. Campbell-Kibler, R.J. Podesva, S.J. Roberts and A. Wong (Eds.) Language and sexuality: Contesting meaning in theory and practice. Stanford: CSLI Publications. pp. 111-134.

Milani, T.M. 2013. Expanding the Queer Linguistic scene: Multimodality, space and sexuality at a South African university. Journal of Language and Sexuality 2(2): 206-234.

Milani, T.M. 2014. Sexed signs - Queering the scenery. International Journal of the Sociology of Language 228: 201-225.

Milani, T.M. 2015. Sexual cityzenship: Discourses, spaces and bodies at Joburg Pride 2012. Journal of Language and Politics 14(3): 431-454.

Milani, T.M. and B. Wolff. 2015. Queer skin, straight masks: Same-sex weddings and the discursive construction of identities and affects on a South African website. Critical Arts 29(2): 165-182.

Motschenbacher, H. and M. Stegu (Eds.) 2013a. Queer linguistic approaches to discourse. Special issue of Discourse \& Society 24(5): 519-648.

Motschenbacher, H. and M. Stegu. 2013b. Queer linguistic approaches to discourse. Discourse \& Society 24(5): 519-535.

Phelan, S. 1997. Sexual strangers: Gays, lesbians, and dilemmas of citizenship. Philadelphia: Temple University Press.

Rowland, V. 29 October 2013. First t-shirt design competition winner announced. Available online: http://www.wits.ac.za/newsroom/newsitems/201310/21889/news item 1889.html (Accessed 25 August 2015).

Sonnekus, T. and J. van Eeden. 2009. Visual representation, editorial power, and the dual 'othering' of black men in the South African gay press: The case of 'Gay Pages'. Communicatio 35(1): 81-100.

Soweto Pride website. Available online: http://www.sowetopride.co.za (Accessed 25 August 2015). 
University of the Witwatersrand. 14 March 2003. University of the Witwatersrand, Johannesburg: Language policy. Available online: http://humanities.ufs.ac.za/dl/userfiles/ Documents/00001/764_eng.pdf (Accessed 8 September 2015).

Warner, M. 1993. Introduction. In M. Warner (Ed.) Fear of a queer planet. Minneapolis: University of Minnesota Press. pp. vii-xiv.

Wits Safe Zones website. Available online: http://www.wits.ac.za/transformationoffice/ 15590/lgbtiaq programmes.html (Accessed 25 August 2015).

Wits Transformation and Employment Equity Office website. Available online: http://www.wits.ac.za/transformationoffice/ (Accessed 25 August 2015).

Yuval-Davis, N. 1997. Gender and nation. Thousand Oaks, CA: Sage. 